\title{
Evaluation of single and interactive toxicities of lead and iron using filtration rate of Zebra mussels (Dreissena polymorpha)
}

\author{
N. Kováts ${ }^{1}$, N.-A. Abdel-Hameid ${ }^{2}$, K. Kovács $^{1}$ \& J. Padisák ${ }^{2}$ \\ ${ }^{I}$ Department of Limnology, University of Pannonia, Hungary \\ ${ }^{2}$ Department of Zoology, Faculty of Science, Egypt
}

\begin{abstract}
The filtration rate of zebra mussels (Dreissena polymorpha), as a sensitive biological end point, was used to evaluate the toxicity of lead and iron. Zebra mussels were exposed individually to serial levels of lead and iron $(800,1000$, $\left.1200,1400,1800 \mu \mathrm{g} \mathrm{L}^{-1}\right)$. The inhibition of filtration rate was determined after $24 \mathrm{~h}$. The bioassay revealed that the effective concentration causing filtration inhibition 1\% (EC1 filtration), 5\% (EC5filtration ), 10\% (EC10filtration), 50\% (EC50filtration) and 99\% (EC99filtartion) of $\mathrm{Pb}$ and $\mathrm{Fe}$ to $\mathrm{D}$. polymorpha were 427.072, 601.310, 721.648, 1373.448, 4416.951 $\mathrm{g} \mathrm{L} \mathrm{L}^{-1}$ and 409.908, 571.420, $682.141,1274.149$ and $3960.532 \mu \mathrm{g} \mathrm{L}^{-1}$, respectively. The ECx values recorded for $\mathrm{Fe}$ were higher than those recorded for $\mathrm{Pb}$. Therefore, $\mathrm{Fe}$ was found to be more toxic to zebra mussels than $\mathrm{Pb}$. The interactive effect of these metals was examined by testing the inhibition of filtration rate of zebra mussels exposed to 1:1 mixture of $\mathrm{Pb}$ and $\mathrm{Fe}$. It was established that their interaction was synergistic. The results show that $\mathrm{D}$. polymorpha filtration rate can be a sensitive end-point for assessing ecological risk of $\mathrm{Pb}$ and $\mathrm{Fe}$ as environmental contaminants.

Keywords: metals, interactive effects, ecotoxicology, zebra mussels, filtration rate.
\end{abstract}

\section{Introduction}

Freshwater and marine bivalves are used globally as bioindicators of water quality and as ecotoxicological test organisms [1-3]. Zebra mussels (Dreissena polymorpha) are sessile organisms that filter the water columns and live attached 
to solid substrates [4]. Although mussels do not filter continuously, it is likely that a single zebra mussel could filter $1 \mathrm{~L}$ of water per day $[5,6]$. Thus, they have been used effectively to assess the contamination of freshwater ecosystems by inorganic $[4,7,8]$ as well as organic pollutants [9-11]. Moreover, zebra mussels have been used in early warning systems [12]. Measuring the mortality as an end point in selected test species allowed the evaluation of environmental disturbances and associated biological effects [13]. For the ecotoxicological assessment of pollutants, there is an ultimate need to use more sensitive biological responses in order to detect the toxic units at low levels. Kraak et al. [14] found that the use of filtration rate of D. polymorpha to assess the toxicity of metals $(\mathrm{Cu}, \mathrm{Zn}, \mathrm{Cd})$ is a responsive parameter. They found that, $\mathrm{Cu}$ LC50 was

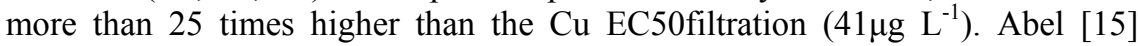
reported for the marine mussel Mytillus edulis that the 96-h LC50 for $\mathrm{Cu}$ and $\mathrm{Zn}$ were 2 and 5 times higher than the EC50filtration. Thus, the uses of sublethal end points are far more realistic for ecotoxicological laboratory assessments than traditional mortality alternatives [14]. Zebra mussel is suitable test organism for ecotoxicological laboratory experiments using filtration rate due to little mortality and high filtration rate in the control [14]. Vijayavel et al. [16] reported that oxygen consumption; filtration and ATPase systems could be used as valid sublethal biomarkers in aquatic ecotoxicological studies.

Although some metals are necessary for normal physiological processes of aquatic organisms, but contact over threshold induces harmful effects or even death [17]. In the presence of elevated metal levels, the bivalves close their shells for longer time [12], exhibit reduced heart beat [18] and filtration rate [19]. Lead is a toxic metal that is present in the environment in tiny amount. Its largest industrial use worldwide is in the manufacture of batteries and it is also used in paints, glazes, alloys, radiation shielding and tank lining. Lead pollution comes from cars, lead smelters, metal processing plants, incinerators and some old paints (http://www.epa.gov/safewater/contaminants/index.html). Although, $\mathrm{Fe}$ is an essential micronutrient, elevated concentrations may limit the animal metabolism [20] and induces oxidative stress [21]. According to EPA, the maximum permissible level of $\mathrm{Pb}$ and $\mathrm{Fe}$ in surface water is 0.015 and 0.3 $\mathrm{mg} \mathrm{L}^{-1}$, respectively (http://www.epa.gov/safewater/contaminants/index.html).

Industrial and municipal wastewaters and urban storm water commonly contain combinations of metals such as copper, lead, and zinc in addition to organic residues, all of which may be directly or indirectly released into recipient aquatic systems [22]. Therefore, studying the ecotoxicological impacts of aquatic ecosystems by mixtures of pollutants is of increasing concern worldwide [23], [24]. The interactive toxic effects of metals in a mixture may be augmented (synergistic) or antagonistic [25]. Thus, the aim of the present study was to assess the lone as well as the interactive toxicity of $\mathrm{Pb}$ and $\mathrm{Fe}$ using filtration rate of D. polymorpha. 


\section{Materials and methods}

\subsection{Mussels collection and laboratory care}

Zebra mussels (D. polymorpha, Pallas) were collected (November 2009) from Lake Balaton at Balatonaliga, (GPS, N 46 59'111"-E 18 09'500"), Hungary. Mussels were acclimatized at a laboratory static system in well aerated tanks. The water of the aquaria was well aerated and changed weekly with Csigere stream water (near Devecser village west Veszprèm, GPS; N 47 07' 081" - E 17 $25^{\prime} 244^{\prime \prime}$, Hungary) to provide the mussels with natural food and to remove the possible accumulation of ammonium. The physical and chemical parameters, total phytoplankton biomass of Csigere stream water are presented in Table 1. They were measured using multi probe portable equipments (Multi HQ $40 \mathrm{~d}$, Hach for DO, PH, conductivity and Hach Lange for turbidity).

Table 1: Some physicochemical characteristics and total phytoplankton noumber and biomass of Csigere stream water.

\begin{tabular}{ll}
\hline Items & Value \\
\hline $\mathrm{pH}$ & 8.1 \\
Dissolved oxygen, mg/1 (\%) & $9.7(88.1)$ \\
Temperature $\left({ }^{\circ} \mathrm{C}\right)$ & 10.4 \\
Conductivity $(\mu \mathrm{ss} / \mathrm{cm})$ & 830 \\
Turbidity $(\mathrm{FNU})$ & 7.84 \\
Phytoplankton noumber $\left(\mathrm{X} 10^{3} / \mathrm{ml}\right)$ & 40.959 \\
Phytoplankton biomass $\left(\mathrm{mg} / \mathrm{m}^{3}\right)$ & 15904.76 \\
\hline
\end{tabular}

\subsection{Bioassay and estimating the total phytoplankton biomass}

Stock solutions of $10 \mathrm{mg} \mathrm{L}^{-1}$ for both $\mathrm{PbCl}_{2}$ and $\mathrm{FeCl}_{3}$ were used to prepare 5 serial concentrations of each metal $\left(800,1000,1200,1400\right.$, and $\left.1800 \mu \mathrm{g} \mathrm{L}^{-1}\right)$. The exposure experiment was done in aerated plastic container (10 liters), containing 2 liters (1 liter Csigere stream water and 1 liter distilled water). The initial total phytoplankton biomass was $7952.38 \pm 302.21 \mathrm{mg} \mathrm{m}^{-3}$ for the control and test groups (Table 1). There were two replicates per each serial concentration and control group. Five mussels (shell length 10-15 mm) were used for each replicate. The bioassay was terminated after $24 \mathrm{~h}$.

The total phytoplanktons in Csigere stream water as well as those in the test water were fixed by adding by few drops of Lygol solution. The total count of every phytoplankton species of each sample was done after at least $24 \mathrm{~h}$ of fixation. Total phytoplankton biomass as $\mathrm{mg} \mathrm{m}^{-3}$ was computed by Hamilton computer software (algamica) based on the method of Gosselain and Hamilton [26].

\subsection{Data analysis}

Using this software, automated calculations of densities, biovolumes, surface areas and carbon biomass were available at the termination of each sample count. 
The data of total phytoplankton biomass were expressed as means \pm standard error. The filtration rate was calculated from the percentage of reduction of total algal biomass in each test concentrations as well as in the control group using the following formula: Filtration rate (\%) $=100$ (Initial biomass-Final biomass/Initial biomass). Inhibition of filtration regarding those of the control was computed using the following formula: Filtartion inhibition $(\%)=100$ (Filtration rate of control-Filtration rate of test/Filtration rate of control). The ECx of tested metals and its confidence limit was computed using EPA probit analysis program version 1.5 .

The interaction of both $\mathrm{Pb}$ and $\mathrm{Fe}$ was examined by exposing duplicate group of mussels to equitoxic (EC50) mixture of both metals. The observed inhibition (observed effect) of filtration rate was estimated from the reduction of total algal biomass. The theoretically expected (PE) effect of the binary mixtures on the test organisms was evaluated using the formula proposed by Kungolos et al. [27] and Hadjispyrou et al. [11]. It was computed using the following formula: $\mathrm{P}(\mathrm{E})=\mathrm{P} 1+\mathrm{P} 2-\mathrm{P} 1 \mathrm{P} 2 / 100$. Where, $\mathrm{P}(\mathrm{E})$ is the theoretical expected effect, $\mathrm{P} 1$ is the inhibition caused by chemical A and $\mathrm{P} 2$ is the inhibition caused by chemical $\mathrm{B}$. This model is based on the hypothesis that the toxicants act concurrently and not successively on the affected organism [24].

\section{Results and discussion}

The data presented in Table (1) showed that Csigere stream water quality was normal and contained high amount of total algal biomass originating from an upstream fish pond. Its algal population was rich with 46 total numbers of taxa and total biomass of $15904.76 \mathrm{mg} \mathrm{m}^{-3}$. In Table 2 gives the filtration rate of $D$. polymorpha expressed as percentage clearance of total algal biomass of the control and those of serial concentrations of $\mathrm{Pb}$ or $\mathrm{Fe}$. The bioassay revealed that the filtration rate of D. polymorpha was repressed due to the exposure to serial levels of $\mathrm{Pb}$ and $\mathrm{Fe}$. Its magnitude varied according to the metal and its levels. In

Table 2: Acute effect $(24 \mathrm{~h})$ of lead and iron on filtration rate of zebra mussel (D. polymorpha).

\begin{tabular}{llllll}
\hline Metals & $\begin{array}{l}\text { Levels }(\mu \mathrm{g} \\
\left.\mathrm{L}^{-1}\right)\end{array}$ & \multicolumn{2}{l}{ Total biomass $\left(\mathrm{mg} \mathrm{m}^{-3}\right)$} & $\begin{array}{l}\text { Filtration } \\
\text { rate }(\%)\end{array}$ & $\begin{array}{l}\text { Filtration } \\
\text { inhibition } \\
(\%)\end{array}$ \\
\cline { 3 - 5 } & & Initial & Final & & (\%) \\
\hline Lead & Control & $7952.38 \pm 302.21$ & $3702 \pm 187$ & $53.45 \pm 4.21$ & - \\
& 800 & - & $4283 \pm 254.35$ & $46.14 \pm 4.55$ & $13.68 \pm 1.05$ \\
& 1000 & - & $4868 \pm 172.37$ & $38.75 \pm 3.87$ & $27.5 \pm 2.85$ \\
& 1200 & - & $5400 \pm 195.56$ & $32.09 \pm 2.66$ & $39.96 \pm 2.39$ \\
& 1400 & - & $5812 \pm 146.22$ & $26.91 \pm 2.46$ & $49.65 \pm 4.61$ \\
& 1800 & - & $6726 \pm 198$ & $15.42 \pm 1.87$ & $71.15 \pm 3.98$ \\
Iron & Control & $7952.38 \pm 302.21$ & $3702 \pm 187$ & $53.45 \pm 4.21$ & - \\
& 800 & - & $4471.58 \pm 206.23$ & $43.77 \pm 3.46$ & $18.11 \pm 1.25$ \\
& 1000 & - & $5100 \pm 197.35$ & $35.87 \pm 3.11$ & $32.89 \pm 2.47$ \\
& 1200 & - & $5398.46 \pm 205.45$ & $32.11 \pm 2.68$ & $39.92 \pm 2.68$ \\
& 1400 & - & $6137.24 \pm 205.22$ & $22.82 \pm 1.79$ & $57.31 \pm 3.94$ \\
& 1800 & - & $7026.47 \pm 179.25$ & $11.64 \pm 1.09$ & $78.22 \pm 4.79$ \\
\hline
\end{tabular}


case of $\mathrm{Pb}$ exposure, the lowest filtration inhibition $(13.68 \pm 1.05 \%)$ was recorded for the lowest $\mathrm{Pb}$ level $\left(800 \mu \mathrm{g} \mathrm{L}^{-1}\right)$ and the highest filtration inhibition $(71.15 \pm 3.98 \%)$ was recorded for the highest one $\left(1800 \mu \mathrm{g} \mathrm{L}^{-1}\right)$. Iron exposure induced a higher filtration inhibition than $\mathrm{Pb}$. The lowest $\mathrm{Fe}$ level induced $18.11 \pm 1.25 \%$ filtration inhibition and the highest one induced $78.22 \pm 4.79 \%$ filtration inhibition (Table 2).

Data are Mean \pm SE. Filtration rate $(\%)=100$ (Initial biomass-Final biomass/Initial biomass). Filtration inhibition $(\%)=100$ (Filtration rate of control-Filtration rate of test/Filtration rate of control).

Table 3: Comparison of different $\mathrm{ECx}$ of $\mathrm{Pb}$ and $\mathrm{Fe}$ based on filtration rate of D. polymorpha.

\begin{tabular}{lll}
\hline $\mathrm{EC}_{\mathrm{x}}$ & $\mathrm{Pb}\left(\mu \mathrm{g} \mathrm{L}^{-1}\right)$ & $\mathrm{Fe}\left(\mu \mathrm{g} \mathrm{L}^{-1}\right)$ \\
\hline $\mathrm{EC}_{1}$ & $427.072(312.925-521.647)$ & $409.908(302.194-500.149)$ \\
$\mathrm{EC}_{5}$ & $601.310(484.577-692.258)$ & $571.420(460.313-659.162)$ \\
$\mathrm{EC}_{10}$ & $721.648(610.877-806.230)$ & $682.141(575.394-764.626)$ \\
$\mathrm{EC}_{50}$ & $1373.448(1293.381-1475.834)$ & $1274.149(1203.732-1355.619)$ \\
$\mathrm{EC}_{99}$ & $4416.951(3474.785-6423.668)$ & $3960.532(3187.951-5526.334)$ \\
\hline
\end{tabular}

95\% confidence limit indicated between parentheses.

The data in Table 3 present the computed $\mathrm{EC}_{1 \text { filtration, }} \mathrm{EC}_{5 \text { filltration, }} \mathrm{EC}_{10 \text { filtration, }}$ $\mathrm{EC}_{50 \text { filtration }}$ and $\mathrm{EC}_{99 \text { filtration }}$ of $\mathrm{Pb}$ and $\mathrm{Fe}$ to D. polymorpha which were 427.072, 601.310, 721.648, 1373.448, 4416.951 $\mathrm{gg} \mathrm{L}^{-1}$ and 409.908, 571.420, 682.141, 1274.149 and $3960.532 \mu \mathrm{g} \mathrm{L} \mathrm{L}^{-1}$, respectively. Although the ECx recorded higher values for $\mathrm{Pb}$ than those for $\mathrm{Fe}$, their $95 \%$ confidence limit overlap indicating nonsignificant differences, meanings that the toxicity of Fe was non-significantly higher than those of $\mathrm{Pb}$. It was found that $D$. polymorpha exposed to equitoxic mixture of both $\mathrm{Pb}$ and $\mathrm{Fe}$ exhibited a significantly higher filtration inhibition than the theoretically expected one. Thus, the interactive effect of both tested metals was synergistic (Table 4).

Bioassays using biological responses other than mortality are more precise and generally the values of EC50 are lower the values of LC50 [28]. Kraak et al. [4] found that zebra mussels collected from Eijsden on the river Meuse (Belgian and Dutch border, km 620) containing elevated levels of $\mathrm{Cu}, \mathrm{Zn}, \mathrm{Cd}$ and $\mathrm{Pb}$ exhibited also low filtration rate, the results compared with reference contamination free water (Lake Markermeer, The Netherlands). Kraak et al. [14] estimated the $48 \mathrm{~h} \mathrm{EC}_{50 \text { filtration }}$ of $\mathrm{Cu}\left(41 \mu \mathrm{g} \mathrm{L}^{-1}\right), \mathrm{Cd}\left(388 \mu \mathrm{g} \mathrm{L}^{-1}\right)$ and $\mathrm{Zn}(1350 \mu \mathrm{g}$ $\left.\mathrm{L}^{-1}\right)$. Loayza-Muro and Elliás-Lettas [3] assessed the inhibition of filtration rate of Anodontites trapesialis (Unionidae) and found that $\mathrm{Cd}$ exerted the most toxic effects (EC50filtration $\left.64 \mu \mathrm{g} \mathrm{L}^{-1}\right)$ followed by $\mathrm{Cu}\left(605 \mu \mathrm{g} \mathrm{L^{-1 }}\right)$ and $\mathrm{Zn}$ $\left(4064 \mu \mathrm{g} \mathrm{L}^{-1}\right)$. 
Table 4: $\quad$ Acute effect ( $24 \mathrm{~h}$ ) of equitoxic binary mixtures of lead and iron on $\%$ inhibition of filtration rate and comparison between theoretically expected and observed interactive effects of zebra mussel (D. polymorpha).

\begin{tabular}{llllll}
\hline Groups & $\begin{array}{l}\text { Total biomass } \\
\left(\mathrm{mg} / \mathrm{m}^{3}\right)\end{array}$ & $\begin{array}{l}\text { Filtration } \\
\text { rate }(\%)\end{array}$ & $\begin{array}{l}\text { Observed } \\
\text { Filtration } \\
\text { inhibition, \% } \\
(\mathrm{O})\end{array}$ & $\begin{array}{l}\text { Theoretically } \\
\text { Expected effect } \\
(\mathrm{E})\end{array}$ \\
\cline { 2 - 5 } & Initial & Final & & - & - \\
\hline Control & 7952.38 & 3702 & 53.45 & - & - \\
& \pm 302.21 & \pm 187 & \pm 4.21 & & 75 \\
$\mathrm{~Pb}+\mathrm{Fe}$ & - & 7364.42 & 7.39 & 86.17 & \\
& & \pm 275.44 & \pm 0.79 & $\pm 3.26 \uparrow$ & \\
\hline
\end{tabular}

Data are Mean \pm SE. Filtration rate $(\%)=100$ (Initial biomass-Final biomass/Initial biomass). Filtration inhibition $(\%)=100$ (Filtration rate of control-Filtration rate of test/Filtration rate of control). $\uparrow$ is significantly higher than $\mathrm{E}$, more than additive.

The results herein reported that the exposure of $D$. polymorpha to $\mathrm{Pb}$ and iron causes inhibition of the filtration rate. This phenomenon was previously reported for other heavy metals and for different species [3, 4, 16, 28]. The present study recorded $24 \mathrm{~h} \mathrm{EC}_{50 \text { filtration }}$ for $\mathrm{Pb}\left(1373.448 \mu \mathrm{g} \mathrm{L}^{-1}\right)$ and $\mathrm{Fe}\left(1274.149 \mu \mathrm{g} \mathrm{L}^{-1}\right)$. This means that $\mathrm{Pb}$ was more toxic than Fe to D. polymorpha. The recorded $24 \mathrm{~h}$ $\mathrm{EC}_{50 \text { filtration }}$ of $\mathrm{Pb}$ was closer to $\mathrm{Zn} 48 \mathrm{~h} \mathrm{EC}_{50 \text { filltration }}\left(1350 \mu \mathrm{g} \mathrm{\textrm {L } ^ { - 1 }}\right)$ recorded previously for zebra mussel by Kraak et al. [14]. The 24 h EC50 value is usually approximately around the half of $48 \mathrm{~h}$ EC50. Thus, it could be concluded that the toxicity of $\mathrm{Zn}$ is greater than $\mathrm{Pb}$ and Fe. Neal et al. [29] reported higher level of $\mathrm{Pb}\left(6.3 \mu \mathrm{g} \mathrm{L}^{-1}\right)$ in river Swale (one of Humber rivers, UK) than the background $\left(0.2 \mu \mathrm{g} \mathrm{L}^{-1}\right)$ but they are less than those reported for major industrial rivers of Europe $\left(57 \mu \mathrm{g} \mathrm{L}^{-1}\right)$ (e.g. the Rhine) and less than the average of environmental

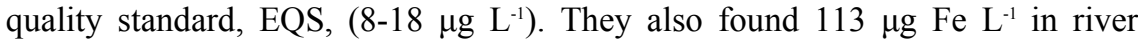
Swale water which is higher than those of Rhine water $\left(35 \mu \mathrm{g} \mathrm{L}^{-1}\right)$ but also below than EQS level (1000 $\left.\mu \mathrm{g} \mathrm{L}^{-1}\right)$. Moss et al. [30] reported ecological relevant levels of $\mathrm{Pb} 30 \mu \mathrm{g} \mathrm{L}^{-1}$ and Fe 20-1195 $\mu \mathrm{g} \mathrm{L}^{-1}$ in crawfish (Procambrus clarkia) pond. By comparing these results with $\mathrm{EC}_{50 \text { filtration }}$ recorded in the present study, it was found that the $\mathrm{Pb}$ level was far low from the $\mathrm{EC}_{50 \text { filtration, whereas the upper limit }}$ of $\mathrm{Fe}$ was less below those of $\mathrm{Fe} \mathrm{EC}_{50 \text { filtration }}$.

The present results found that the mixture of $\mathrm{Pb}$ and $\mathrm{Fe}$ exerted synergistic toxic effect to $D$. polymorpha. This result was in agreement with those reported earlier by Cooper et al. [31] for mixture of copper, lead and zinc using immobilization test of Cladoceran species, Daphnia carinata and Ceriodaphnia dubia. Interaction of metals may be influenced by the species being tested, combination of metals or water quality [31]. Sephar and Fiandt [32] declared that the same combinations of metals (arsenic, cadmium, chromium, cooper, mercury and lead) showed different interactive effects depending on both species exposed and the end point tested. The same authors found that when daphnids are used as 
the test organisms the effects are almost strictly additive or nearly additive for acute and chronic exposures, respectively.

The data of this study reiterate that the use of filtration rate of $D$. polymorha could be useful biomonitoring test for evaluating the toxicity of $\mathrm{Pb}$ and $\mathrm{Fe}$. Also, the toxicity of $\mathrm{Fe}$ was higher than $\mathrm{Pb}$ and their interaction was strictly additive.

\section{Acknowledgements}

The authors are appreciative of the immense efforts by Mrs. Zámbóné Doma Zsuzsa, the technician at Department of Limnology, University of Pannonia for counting and estimating the total algal biomass.

\section{References}

[1] Boening, D. W., An evaluation of bivalves as biomonitors of heavy metals pollution in marine waters. Environmental Monitoring and Assessment, 55, 459-470, 1999.

[2] Kádár, E., Salánki, J., Powel, J., White, K.N., McCorhan, C.R., Effect of sublethal concentration of aluminium on the filtration rate activity of the freshwater mussel Anodonta cygnea L. at neutral pH. Acta Biologica Hungarica 53, (4), 485-493, 2002.

[3] Loayza-Muro, R., Elliás-Letts, R., Response of the museel Anodonties trapesialis (Unionidae) to environmental stressors: Effect of $\mathrm{pH}$, temperature and metals on filtration rate. Environmental Pollution, 149, 209-215, 2007.

[4] Kraak, M.H.S., Kupiers, F., Schoon, H., de Groot, C. J., Admiraal W., The filtration rate of the zebra mussel Dreissena polymorpha used for water quality assessment in Dutch rivers. Hydrobiologia, 294, 13-16, 1994.

[5] Griffiths, R. W., Schloesser, D. W., Leach, J. H., Kovalak, W. P., Distribution and Dispersal of the Zebra Mussel in the Great Lakes Region. Canadian Journal of Fisheries and Aquatic Sciences, 48, 1381-1388, 1991.

[6] Balogh, C., The settling, quatitative trend, filtration rate of zebra mussel (Dreissena polymorpha) and the effect of the mussel on the matter-energy flux and on the bacterial community. Ph.D. Thesis, University of Pannonia, Environmental Sciences Ph.D. School, Veszprèm, pp., 11, 2008.

[7] Johns, C., Timmerman, B.E., Total cadmium, copper, and zinc in two dreissenid mussels, Dreissena polymorpha and Dreissena bugenesis, at the outflow of lake Ontario. Journal of Great lakes Research, 24, 55-64, 1998.

[8] Camusso, M., Balestrini, R., Binelli, Use of zebra mussel (Dreissena polymorpha) to assess trace metal contamination in the largest Italian subalpine lakes. Chemosphere, 44, 263-270, 2001.

[9] Kraak, M.H.S., Ainscough, C., Fernández, A., van Vlaardingen, P.L.A., de Voogt P., Admiral, W.A., Shor-tem and chronic exposure of the zebra mussel (Dreissena polymorpha) to acridine. Aquatic Toxicology, 37, 9-20, 1997. 
[10] Hendriks, A. J., Pieters, H., Boer, J., Accumulation of metals, polycyclic halogenated aromatic hydrocarbons and biocides in zebra mussel and eel from the Rhine and Menuse rivers. Environmental Toxicology and Chemistry, 17, 1885-1898, 1998.

[11] Hadjispyrou, S., Kungolos, A., Anangostopoulos, A., Toxicity, bioaccumulation and effects of organotin, cadmium and chromium on Artemia franciscana. Ecotoxicology and Environmental Safety, 49, 179$186,2001$.

[12] Krammer, K.J.M., Jenner, H.A., de Zwart, D., The valve movement response of mussels: a tool in biological monitoring. Hydrobiologia, 199/189, 433-443, 1989.

[13] Soucek, D.J., Schmidt, T.S., Cherry, D.S., In situ studies with Asian clams (Corbicula fluminea) detected acid mine drainage and nutrients input in low order streams. Canadian Journal of Fisheries and Aquatic Science, 58, 602608, 2001.

[14] Kraak, M.H.S., Toussaint, M., Lavy, D., Davids C., Short-term effects of metals on the filtration rate of the zebra mussel Dreissena polymorpha. Environmental pollution, 84, 139-143, 1994b.

[15] Abel, P.D., Effect of some pollutants on filtration rate of Mytillus. Marine Pollution Bulletin, 7(12), 228-231, 1976.

[16] Vijayavel, K., Gopalakrishnan, S., Balasubramanian, M. P., Sublethal effect of silver and chromium in the green mussel Perna viridis with reference to alterations in oxygen uptake, filtration rate and membrane bound ATPase system as biomarkers. Chemosphere, 69, 979-986, 2007.

[17] Bossuyt, B.T.A., Janssen, C.R., Acclimation of Daphnia magna to environmentally realistic copper concentrations. Comparative Biochemistry and Physiology Part C, 136, 253-264, 2003.

[18] Grace, A. L., Gainey Jr., The effects of copper on heart rate and filtration rate of Mytillus edulis. Marine Pollution Bulletin, 18(2), 87-91., 1987.

[19] Redpath, K.J., Davenport, J., The effect of copper, zinc and cadmium on the pumbing rate of Mytilus edulis L. Aquatic Toxicology, 13, 217-226., 1988.

[20] Halliwell B., Gutteridge J.M.C., Free radicals in biology and medicine. Academic Press, London, 1985.

[21] Koster, J.T., Slee, RG, van Berkel, C., On the lipid peroxidation of rat liver hepatocytes, the formation of fluorescent chromolipids and high molecular weight protein. Biochemica et Biophysica Acta, 710, 230-235., 1982.

[22] Gobeil, C.; Rondeau, B., Beduin, L., Contribution of municipal effluents to metal fluxes in the St. Lawrence River. Environmental Science and Technology, 39, 456-464., 2005.

[23] Shaw, J. R., Dempsey, T.D., Chen, C. Y., Hamilton, J.W., Folt, C. L., Comparative toxicity of cadmium, zinc and mixtures of cadmium and zinc to daphnids. Environmental Toxicology and Chemistry, 25, 182-189, 2006.

[24] Kungolos, A., Emmanouil, C., Tsiridis, V. N., Tsiropoulos, N., Evaluation of toxic and interactive toxic effects of three agrochemicals and copper 
using a battery of microbiotests. Science of the Total Environment, 407(16), 4610-4615., 2009.

[25] Enserink, E.L., Maas-Diepeveen, J.L., van Leeuwen, C.J., Combined effects of metals; an ecotoxicological evaluation. Water Research, 25, 679687, 1991.

[26] Gosselain, V., Hamilton, P.B., Algamica: revisions to a key-based computerized counting program for free-living, attached, and benthic algae. Hydrobiologia, 438, 139-142, 2000.

[27] Kungolos, A., Samaras, P., Kipopoulou, A.M., Zoumboulis, A. Sakellaropoulo, G.P., Interactive toxic effects of agrochemicalson aquatic organisms. Water Science and Technology, 40 (1), 357-364., 1999.

[28] Arambašic, M.B., Bjelić, S., Subakov, G., Acute toxicity of heavy metals (copper, lead, Zinc), phenol and sodium on Allium cepa L., Lepidium sativum L. and Daphnia magna St.: Comparative investigations and the practical applications. Water Research, 29, 497-503., 1995.

[29] Neal, C., Smith, C.J., Jeffery, H.A., Jarvie, H.P., Robson, A. J., Trace element concentrations in the major rivers entering the Humber estuary, NE England. Journal of Hydrology, 182, 37-64., 1996.

[30] Moss, J. C., Hardaway, C. J., Richert, J. C., Sneddon, J., Determination of cadmium copper, iron, nickel, lead and zinc in crawfish (Procambrus clarkii) by inductively coupled plasma optical emission spectrometry: A study over the 2009 season in Southwest Louisiana. Michrochemical Journal, 95 (1), 5-10., 2010.

[31] Cooper, N. L., Bidwell, J. R., Kumar, A., Toxicity of copper, lead and zinc mixtures to Ceridaphnia dubia and Daphnia magna. Ecotoxicology and Environmental Safety, 72, 1523-1528., 2009.

[32] Sephar, R.L., Fiandt, J. T., Acute and chronic effects of water quality criteria based mixtures on three aquatic species. Environmental Toxicology and Chemistry, 5, 917-931., 1986. 